\title{
ІНТЕРФЕЙС ЕЛЕКТРОННОÏ МЕДИЧНОЇ КАРТКИ НА МОБІЛЬНОМУ ПРИСТРОї
}

\author{
Ю. Л. Нечипоренко \\ Енергодарський інститут державного та муніципального управління ім. Р. Г. Хеноха \\ "КАасичного приватного університету"

\begin{abstract}
Розроблено концепцію електронної медичної картки для гетерогенного середовища медичних інформаційних
\end{abstract} \\ систем різного рівня. Запропоновано відповідну модель і технічне рішення. Здійснено оцінювання операційних \\ систем для мобільних пристроїв. Розроблено та створено проект мобільного додатку на OC Android у вигляді \\ електронної медичної карти на планшетному ПК Acer.
}

Ключові слова: електронна медична картка, мобільний пристрій, OC ANDROID, IDE, JAVA, SDK, XML, ECLIPSE.

\section{ИНТЕРФЕЙС ЭЛЕКТРОННОЙ МЕДИЦИНСКОЙ КАРТОЧКИ НА МОБИЛЬНОМ УСТРОЙСТВЕ}

\author{
Енергодарський институт государственного и муниципального управления \\ им. Р. Г. Хеноха "Классического частного университета"
}

\begin{abstract}
Разработана концепция электронной медицинской карточки для гетерогенной среды медицинских информационных систем разного уровня. Предложена соответствующая модель и техническое решение. Осуществлено оценивание операционных систем для мобильных устройств. Разработан и создан проект мобильного дополнения на OC Android в виде электронной медицинской карты на планшетном ПК Аcer.
\end{abstract}

Ключевые слова: электронная медицинская карточка, мобильное устройство, OC ANDROID, IDE, JAVA, SDK, XML, ECLIPSE.

\section{INTERFACE ELECTRONIC MEDICAL CARD ON MOBILE DEVICE}

\author{
Y. L. Nechyporenko \\ Energodar Institute of State and Municipal Management by RG Henoha \\ "Classic Private University"
}

The concept designed by electronic medical card for heterogeneous environment of medical information systems at various levels. Appropriate model and technical solution. Done evaluating operating systems for mobile devices. Designed and produced by the project mobile application on Android OS as an electronic medical record on a Tablet PC Acer.

Key words: electronic health card, mobile device, OS ANDROID, IDE, JAVA, SDK, XML, ECLIPSE.

Вступ. У результаті порівняння специфікацій функцій систем підтримки електронної медичної картки (ЕМК) встановлено, що існує тенденція залучення мобільних пристроїв до ведення масиву медичних даних, тому доцільна розробка ЕМК, що може бути встановлена на особистому мобільному пристрої користувача (пацієнта). Доцільно врахувати при проектуванні ЕМК специфікацію функцій, яка сформована в результаті огляду джерел, організувати сполучення мобільної ЕМК з різними медичними інформацій- ними системами (MIC) медичних закладів, застосування Інтернет-сервісів [1].

Мета дослідження - розробка користувацького інтерфейсу електронної медичної картки (ЕМК) на мобільному пристрої.

Методи досліджень. Програмування здійснювали з застосуванням програмних продуктів Android SDK, Eclipse IDE, AVD Manager та мов програмування Java тa Xml.

ЕМК як невід'ємний елемент сучасної електрон-

(C) Ю. Л. Нечипоренко 
ної МІС має бути спроектованою таким чином, щоби вона містила дані, зміст та обсяг яких регламенте- вано існуючими державними та міжнародними нормативами (рис. 1).

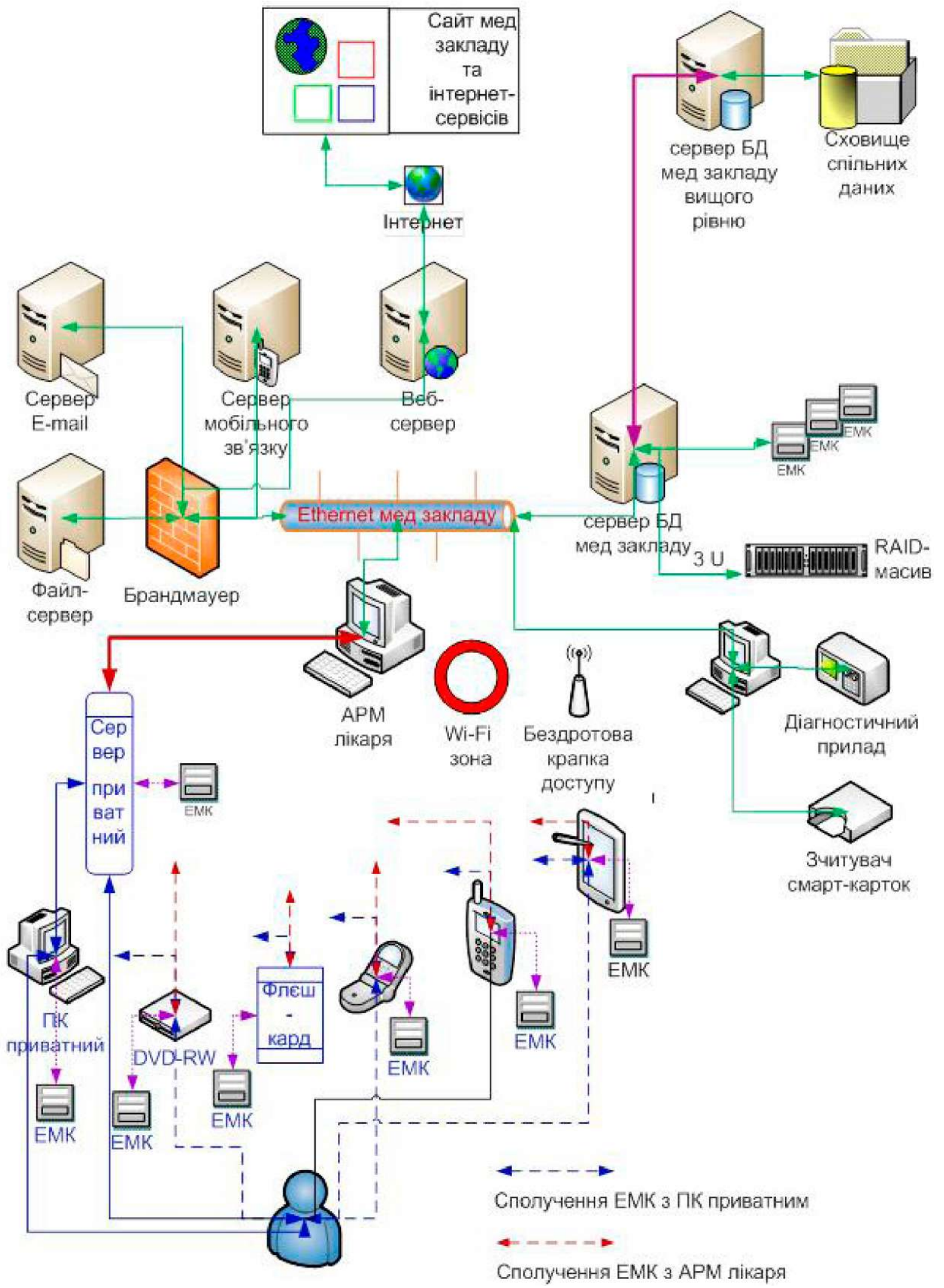

Puc. 1. Модель гетерогенного середовища сполучення ЕМК, розміщеної на пристроях різних типів, з інформаційною системою медичного закладу. 
ЕМК має зберігати в єдиному місці великий обсяг даних протягом життя свого власника, належити особисто людині, дані про яку накопичуються в ЕМК, експортувати/імпортувати дані в існуючому гетерогенному середовищі МIC різного рівня та електронного медичного обладнання.

Запропоновано модель гетерогенного середовища сполучення ЕМК, розміщеної на пристроях різних типів, з МІС медичного закладу. Модель містить різноманітні види пристроїв, на яких може бути розміщена особиста ЕМК: компакт-диск, flash-card, мобільний телефон, смартфон, планшетний комп'ютер, приватний сервер. МІС представлено у вигляді сукупності автоматизованих робочих місць (АРM) лікарів та персоналу медичного закладу, сервера баз даних, файл-сервера, сервера e-mail, сервера мобільного зв'язку, веб-сервера, сайту медичного закладу з розміщеними на ньому інтернет-сервісами, брандмауера, сукупності електронних медичних діагностичних приладів, зчитувача смарт-карток, RAIDмасиву які взаємодіють між собою через Ethernet. MIC має вихід на сервер медичного закладу вищого рівня, районного, міського тощо. Сполучення ЕМК 3 MIC може бути організоване через АРМ лікаря, Інтернет, електронну пошту, мобільний зв'язок.

Технічне рішення. Серед перелічених пристроїв, на яких може бути розміщена особиста ЕМК, можна виділити смартфон, планшетний комп'ютер як такі, що мають розвинену функціональність, набувають все більшого поширення. Розглядаючи можливість застосування мобільних пристроїв таких як смартфон, планшетний ПК, треба відмітити, що якість мобільного пристрою залежить від його апаратних характеристик і від застосованої операційної системи (OC). Проаналізовано поширені ОС для мобільних пристроїв (Symbian, Windows Mobile, Android, iPhone) 3 метою обрання найбільш придатної для розміщення ЕМК на мобільному пристрої.

Якість смартфона залежить від його апаратних характеристик, а функціональність в більшій мірі залежить від застосованої ОС. Тому дуже важливо підібрати не тільки хороші апаратні характеристики, потрібно ще вибрати ОС, з якою користувачеві буде зручно працювати. Програми, написані спеціально для ОС смартфона або планшетного комп'ютера, є повноцінними скомпільованими в двійкові коди послідовностями низькорівневих мікропроцесорних команд. Спеціалізовані програми для смартфонів і планшетних комп'ютерів раціональніше використовують ресурси процесора i, як правило, мають більший функціонал, ніж «універсальні» I2ME-програми для мобільних телефонів.
ОС є сполучною ланкою між апаратною платформою і програмами, що на ній виконуються. При цьому в ОС у вигляді бібліотек і модулів зібрані найбільш часто використовувані стандартні набори команд, що дозволяє спростити проектування програмного забезпечення та скоротити час розробки. Типовими представниками таких наборів команд є драйвери зовнішніх портів введення-виведення, реалізації стека протоколів, графічний інтерфейс, набір специфічних механізмів для розробки програмного продукту тощо.

OC Symbian - це наступник OC ЕРОС. В 1998-2000 роках більшу частину ОС переписали для оптимізації програмного коду для роботи на пристроях, які мають обмежену кількість ресурсів. Розробникам Symbian OS вдалося домогтися значної економії пам'яті, поліпшення кешування програмного коду, а значить прискорення роботи програм під Symbian OS, при цьому враховуючи знижені вимоги до енергоспоживання. Відмітною особливістю Symbian OS є повністю об'єктно-орієнтована архітектура на рівні API. Symbian OS в модифікації Series 60 є основною платформою для смартфонів компанії Nokia. Вона розроблена для пристроїв 3 телефонною клавіатурою, яка має скорочений набір кнопок, і для пристроїв, які мають повнорозмірну клавіатуру. Основними мовами розробки додатків для Symbian OS є C++, OPML, а також є підтримка Јava-додатків [2].

Windows Mobile (WM) являє собою OC для мобільних пристроїв на базі платформи Windows CE. Найбільш популярними є моделі комунікаторів з сенсорним дисплеєм, для яких випускається основна маса всіх додатків для WM. У програмній начинці гаджетів на основі WM присутній стандартний набір додатків: Internet Explorer, Windows Live, Windows Media Player, Office Mobile та інших [3].

Платформа Android для мобільних телефонів, смартфонів, комунікаторів на базі OC Linux (ядро v2.6) підтримується альянсом Open Handset Alliance (OHA), який ініціювала компанія Google [4]. Платформа Android легко пристосовується для використання на VGA, 2D графічних бібліотек розроблених на основі специфікації OpenGL ES 1.0, а також традиційних інструментів для смартфонів. Android використовує базу даних для структурованих даних. Підтримує велику кількість технологій, які забезпечують зв'язок, включаючи: GSM, Bluetooth, EDGE, 3G i WiFi. Для обміну повідомленнями доступні як SMS, так і MMS-сервіси, включаючи і потокові повідомлення. На Android доступний браузер розроблений на основі WebKit application framework, є можливість запускати програми на Java. Android підтримує формати аудіо/відеоданих та зображень MPEG-4, H.264, MP3, AAC, AMR, JPG, PNG, 
GIF. 3 нестандартного обладнання присутня підтримка відеокамери, фотоапарата, тачскрина, GPS, компаca, акселерометра, прискорювача 3D графіки. У 2008 році ОНА опублікував вихідний код платформи Android. У реліз увійшов весь стек Android: операційна система, проміжне ПЗ (middleware), основні кінцеві додатки, написані на Java.

iPhone - ОС для мобільних пристроїв на основі ядра Darwin. Розмір самої ОС не перевищує 200 Мб. В нової версії в ОС присутні понад 110 нових функцій і можливостей. Ця система сумісна 3 такими пристроями, як iPhone 3G, 3GS, iPod Touch нового покоління. Принципова відмінність iOS 4 від усіх попередніх аналогів - з'явилися такі можливості, як одночасний запуск декількох додатків; спрощено роботу з браузером Safari; більш продумана інтеграція з різними сервісами [5].
Розглядаючи мобільні пристрої треба аналізувати їх здатність захищати конфіденційні дані, які містяться в МIC. Сучасні пристрої не лише значно спрощують та розширюють можливості комунікації, а й створюють загрозу безпеці через їхню здатність підключатися до Інтернету. Для усунення цієї небезпеки розроблено вже велику кількість антивірусів, наприклад Kaspersky Mobile Security 9, призначених для захисту смартфонів на базі Android, Symbian, BlackBerry i Windows Mobile від шкідливого ПЗ шляхом здійснення низки заходів безпеки. У Android Market можна безкоштовно закачати та встановити антивірусні додатки, які мають потужний функціонал [6].

Оцінювання проведено на основі обстеження Інтернет-ресурсів і не є абсолютно точним, але дає уявлення про ОС (табл. 1).

Таблиця 1. Порівняння мобільних ОС для мобільних пристроїв

\begin{tabular}{|c|c|c|c|c|c|}
\hline \multirow{2}{*}{ № } & \multirow{2}{*}{ Критерії оцінювання } & \multicolumn{4}{|c|}{ Платформа } \\
\hline & & Windows phone & Symbian & Android & iOS \\
\hline 1 & Розробник & Microsoft & Nocia & Google & Apple \\
\hline 2 & Вік на ринку & 1 & 12 & 3 & 3 \\
\hline 3 & Вихідний код & закритий & відкритий & відкритий & відкритий \\
\hline 4 & Тип ядра & гібридний & мікроядро & монолітне & гібридний \\
\hline 5 & Архітектури процесорів & ARM & ARM, x86 & ARM, x86 & ARM \\
\hline 6 & Дружність інтерфейсу & 5 & 3 & 5 & 4 \\
\hline 7 & Продуктивність системи & 4 & 1 & 4 & 5 \\
\hline 8 & Багатозадачність & ні & так & так & так \\
\hline 9 & Кількість додатків & 50000 & 100000 & 630000 & 480000 \\
\hline 10 & Оновлення ОС & Fota/Data & Fota/Data & Fota/Data & Data \\
\hline
\end{tabular}

Враховуючи наведені дані можна вважати перспективною для розробки мобільних додатків ОС Android, яка є відкритою, поширеною, активно підтримується розробником, має невелику вартість додаткових модулів.

На звичайному ПК встановлено програмні засоби Java SDK - JDK, Android SDK, Eclipse, ADT, платформу Android, запущено емулятор мобільного пристрою. Інтерфейс проекту мобільної ЕМК реалізовано на планшетному ПК Acer з ОС Android. Розроблений проект ЕМК (на даний момент) має форму для авторизації; основне меню програми, яка включає такі форми як ЕМК, довідник ліків, довідник захворювань, форма синхронізації, форма передачі даних на сервер, додаткові модулі, які можливо підключити у платній версії програми; форми для введення та для перегляду даних. Для перенесення ЕМК, яка розроблена на звичайному ПК, вона може бути запакована у формат .apk у програмі Eclipse і встановлена на будь який мобільний пристрій, який працює на О С Android.
Отримані результати. Розроблено та створено проект мобільного додатку на ОС Android у вигляді EMK.

Висновок. Розроблено концепцію ЕМК для гетерогенного середовища МІС. Запропоновано відповідну модель і технічне рішення. Здійснено оцінювання та вибір ОС для мобільних пристроїв. Розроблено та створено проект мобільного додатку на OC Android у вигляді електронної медичної карти на планшетному ПК Acer.

Спроектована ЕМК на мобільному пристрої може бути використана для створення персональної системи моніторингу здоров'я людини.

Подальший розвиток програмної системи може здійснюватись в напрямі приведення ЕМК на мобільному пристрої у повну відповідність до форм MO3У, HL7, організації інтеграції та взаємодії ЕМК на мобільних пристроях різних типів з інформаційною системою медичного закладу. 


\section{Лiтература.}

1. Нечипоренко Ю. Л. Системи підтримки електронних медичних карток / Ю. Л. Нечипоренко. Запорожский медицинский журнал. - 2012. - №6.

2. Simbsan OS. http://www.smartphone.ua/w symbian-os.html

3. Windows Moblile. http://www.smartphone.ua/w_windows- mobile.html

4. Android OS. http://android.com.ua/android_os.html

5. iPhone. http://www.smartphone.ua/w ios-4.html

6. Додатки для Android. http://www.android-market.com.ua/ 